\title{
On the Intergenerational Transmission of Health Inequality
}

\author{
Donne Will, ${ }^{1}$ Fuzhou Wang ${ }^{2,{ }^{*}}$ \\ 1. Group of Ethics and Humanity, Division of Society and Politics, The BASE, Chapel Hill, NC 27510, USA \\ 2. Group of Neuropharmacology and Neurophysiology, Division of Neuroscience, The BASE, Chapel Hill, NC 27510, USA \\ ${ }^{*}$ : All corresponding should be sent to Dr. Fuzhou Wang. \\ Authors'Contact: Donne Will, Ph.D., E-mail: donne.will@basehq.org; Fuzhou Wang, M.D., Ph.D., E-mail: fred.wang@basehq.org. \\ DOI: https://doi.org/10.15354/si.21.re262 \\ The authors declare no competing interest.
}

\begin{abstract}
Cumulating evidence from social science has indicated the intergenerational transmission of inequality is majorly derived from the economic imbalance. In line with this, the same thing happens in health, and emerging evidence has been documenting its transmissible property. No matter the genetic or non-genetic causes, health inequality inevitably plays its role in contributing to the underlying health-associated despoliation in life. Each individual shows an eventual health state where equality and inequality reach a time-dependent temporary condition in which the balancing point fluctuates back and forth. To promote the overall health status, it is crucial to promote and optimize the positive health characteristics to get equilibrium between positive and negative. This review discussed the underlying mechanisms of intergenerational transmission of health inequality by focusing on different types of contributors to the inequality and providing prospective insights into the potentially beneficial strategies that can optimize overall individual health.
\end{abstract}

Keywords: Inequality; Intergenerational transmission; Health; Epigenetics; Equilibrium

Science Insights, 2021 December 28; Vol. 39, No. 5, pp.407-418.

() 2021 Insights Publisher. All rights reserved.

Creative Commons Non Commercial CC BY-NC: This article is distributed under the terms of the Creative Commons Attribution-NonCommercial 4.0 License which permits non-commercial use, reproduction and distribution of the work without further permission provided the original work is attributed by the Insights Publisher.

\section{Introduction}

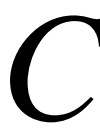

ASE \#1: A 55-year-old Asian female, visiting her daughter here in the USA for six months, was a former farmer in her original country. Tuberculosis (TB) test was positive, and she had liver cirrhosis. She underwent TIPS and TB treatment for four months. Three months post-TIPS, the patient complained of difficulty swallowing and passing through the esophagogastroduodenoscopy, so esophageal carcinoma was suspected. Given the high risk of biopsy, the patient received palliative stenting of the esophagus. The patient's family history indicated that her oldest daughter has HBV infection, her younger son had $H B V$ infection and $T B$, and her younger daughter had TB with treatment completed. This patient had low health consciousness caused by poor economic conditions, which caused her to be unaware of the whole process of disease development. As a result, she lost the opportunity of effective treatment until the end-stage of the disease. This is a typical case of intergenerational transmission of "economic-health" inequality.

Inequality plagues the world everywhere (1). When everyone expects equality, it is actually just a utopian idealized theoretical form. Just like "Yin-Yang", there is always a shift between equality and inequality, and the balance between the two 


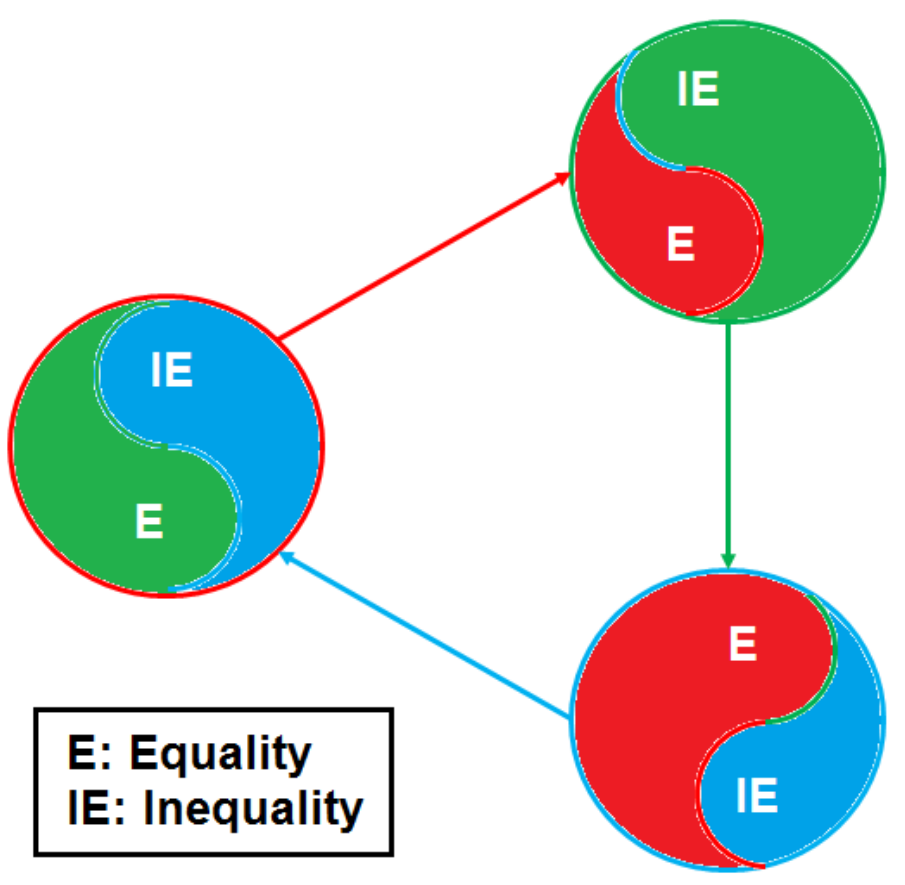

Figure 1. The Equilibrium between Equality and Inequality.

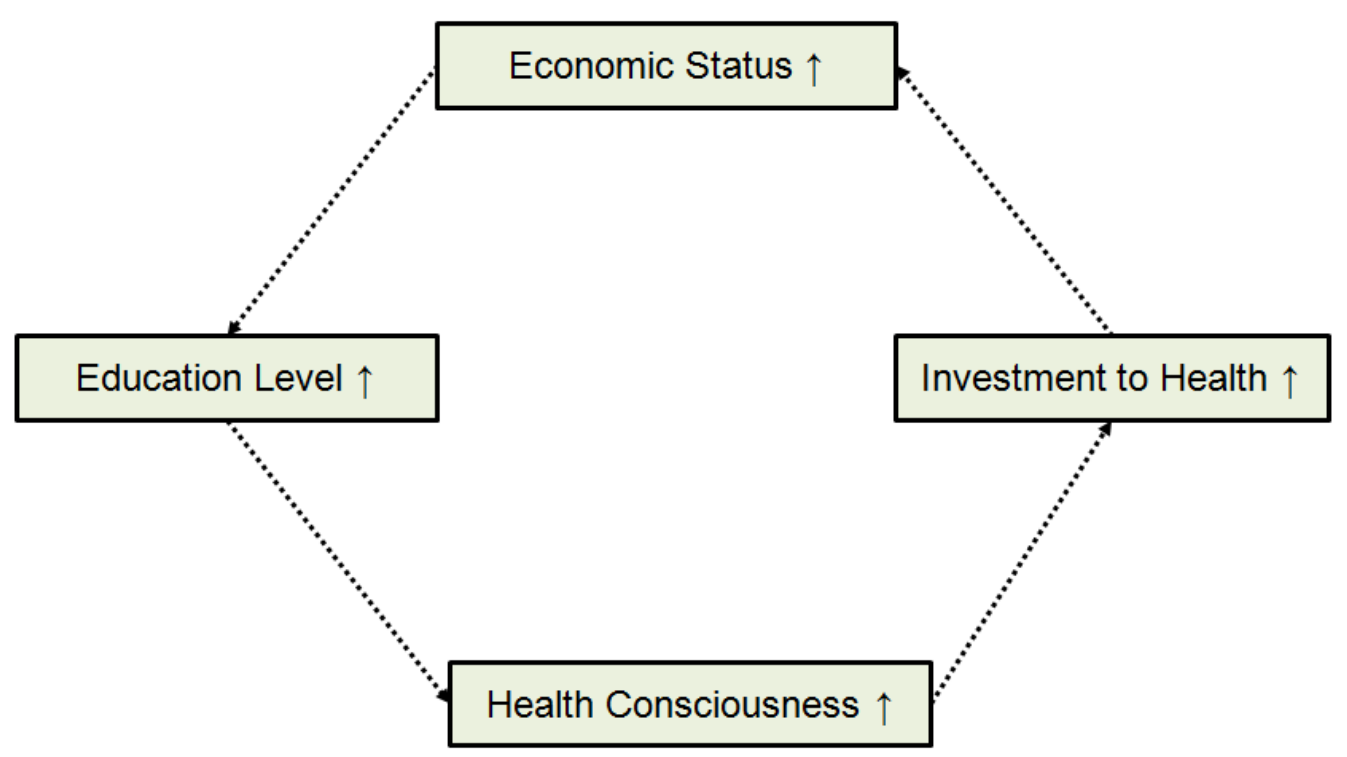

Figure 2. Interaction between Economy, Education, and Health.

is also moving always. As far as the whole system is concerned, it exists in a state of equilibrium between both (Figure 1).

The underlying deep equality has various external manifestations of inequality. The occurrence of inequality stems from many reasons. It is a multi-factor carrier, which includes both external and internal factors. In most cases, the economy is often regarded as the most critical cause of inequality (2-4). However, it can only be one of the possible external factors. Even so, the economy is still inextricably linked to various types of inequality, and it will be transmitted between generations due to differences in economic levels $(5,6)$.

As the basic external manifestation of individuals, health 
has obvious characteristics of inequality $(7,8)$. First of all, in terms of genetic traits, each of us has health differences since birth. Although we cannot accurately distinguish between the conditions of the mother before birth and the impact of investment in childhood after birth, health inequality has existed since the beginning and significantly affects the overall long-term outcome of the individual (9). Moreover, the long-term outcome caused by this kind of health inequality will be combined with its own genetic information to be transmitted between generations (10).

Naturally, genetic inheritance is the biological basis for intergenerational transmission of health inequality. Especially when genetic diseases exist, the resulting intergenerational transmission of health inequality is even more obvious. Regardless of the genetic disease, the result is that the health of the offspring is seriously affected, and a negative vicious positive feedback loop that is closely related to its economic status is generated. Thus, the magnification of this inequality is passed on from generation to generation indefinitely (1). Not merely that, genetically related health inequality can hardly be blocked, and the only way to block it is the generation severance.

In addition to the intergenerational transmission of health inequality caused by genetic factors, external social factors are also one of the important contributors that cause health inequality to occur and achieve intergenerational transmission, such as smoking and alcoholism $(11,12)$. These social factors themselves (such as smoking) will be transmitted between generations, and the resulting health problems will inevitably lead to more bad habits and poor economic conditions related to the intergenerational transmission of unfavorable health (13). Because families with poorer economic conditions are more likely to be affected by social undesirable factors, the resulting health inequality is more likely to be transmitted between generations through their poor economic conditions $(14,15)$ (Figure 2).

Differences in economic conditions are often regarded as one of the underlying causes of acquired health inequality. It is easy to be understood and apparent. Macroscopically, the regional economy level is closely related to the overall health of local residents (16). A direct manifestation is a direct correlation between the average life expectancy of residents and the economic level (17). At the micro-level, the financial status of a family is closely related to the health of family members (18).

In most cases, the economic level is positively correlated with the family's education level, and high-level education dramatically improves health awareness, which will undoubtedly enable such families to make more investments in the health of their members (19). Therefore, the excellent family economic level is precisely a very pivotal endorsement of the health of its members. On the contrary, low-income family finances will turn the whole situation in the opposite direction (20).

\section{Mechanisms \\ Genetic Inheritance}

Case \#2: A 42-year-old Caucasian female, a practicing nurse, has a family history of maternal diabetes mellitus (DM). She was diagnosed with Type 1 DM at the age of five with the primary treatment of insulin injection. At 38 years old, she underwent below-knee amputation due to
$D M$ vascular disease in the left lower extremity. The second toe of the right foot was amputated due to a non-healing wound at 39 years. At the age of 42, the right lower extremity circulatory disorder was diagnosed, and both kidneys were end-stage renal disease stage 4, and she was on the list of kidney transplantation. She was no longer working since the below-knee amputation on the left. Due to her physical disability, her economy and quality of life have declined significantly. She lost hope in life and was subsequently diagnosed with severe depression and attempted two suicides. This is a typical case of intergenerational transmission of health inequality caused by genetic factors.

The transmission of DNA sequence from one generation to the next is the underlying basis of genetic inheritance that works the same for the normal phenotype and the abnormal as well (21). Disease-related genetics is an unavoidable underlying cause that maintains and transmits the pathogenic genes to offspring. Suppose specific disease-causing genes exist in a family. In that case, the health challenges faced by the family under the same external conditions and environment are more significant than those of non-pathogenic gene-carrying families. The transmission of health inequality between generations of the family happened naturally. There is currently nothing to be done about the unequal intergenerational transmission of health with genetic genes as the underlying cause. The so-called gene therapy would leave a vicious cycle without improving a patient's health (22). The only thing we can do is optimize the acquired environment to reduce the adverse effects of genetic diseases or delay the occurrence of genetic disorders (23). Of course, does this genetic-related health inequality mean that future generations are unequal in any other respect? The answer is obviously no. This is a highly complex situation, and various events are interrelated. But what is certain is that this kind of intergenerational transmission of health inequality must impact the offspring (24). Still, it is of different degrees and significantly affected by the external environment. Health inequality from genetic inheritance is not our focus herein of this review.

\section{Non-genetic Reasons Epigenetic Signature}

Epigenetics is a molecular process that is different from genetics, which does not change the DNA sequence in the organism but only modifies and regulates the genome (25). It includes DNA methylation, acetylation, microRNA interaction, phosphorylation, etc. Epigenetic mechanisms modify individual responses to environmental factors (26). It has been confirmed that epigenetic information can be transmitted between generations (27, 28). Whether in animals or humans, epigenetic changes caused by the environment cannot be ignored in the phenotypic modification of offspring (29). This has become the mainstream mechanism and cause of intergenerational transmission of health inequality (30).

Generally, three possibilities exist for the offspring to be exposed to the environment (31): (i) in utero exposure of developing embryos (F1); (ii) prenatal exposure of the fetus (F2); (iii) the third generation (F3) still has the phenotypic changes come from embryos of the first generation (Figure 3). 


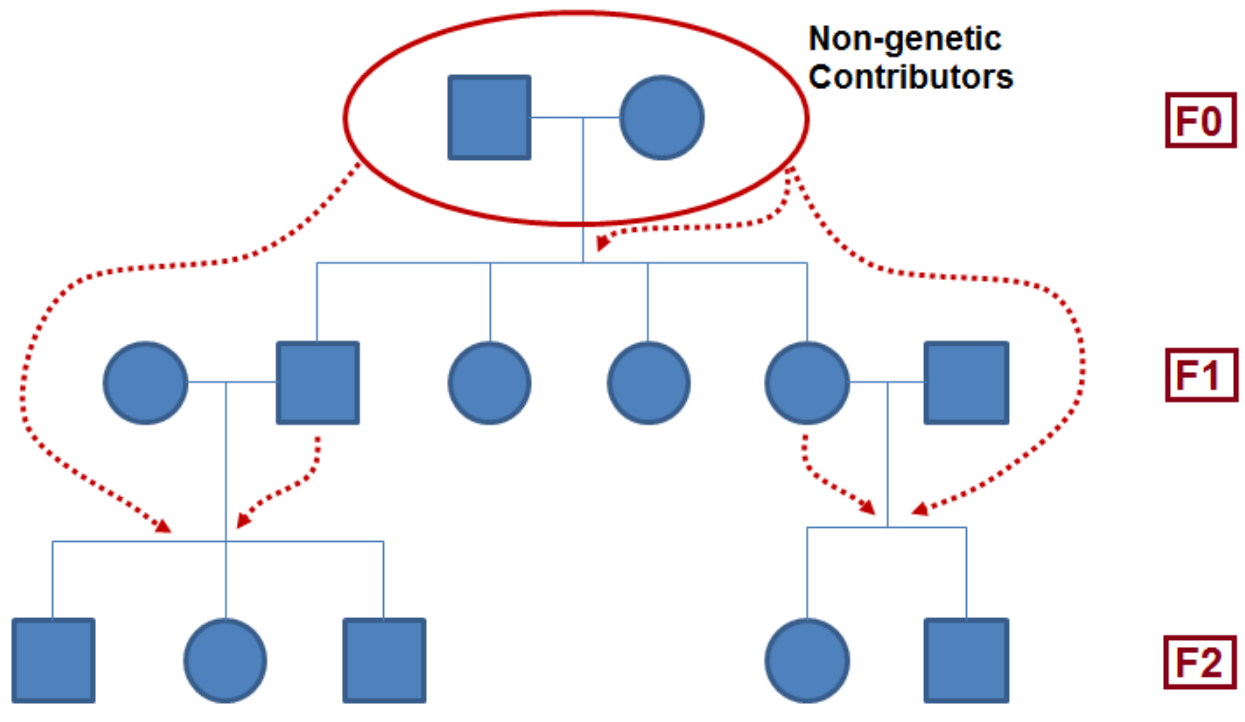

Figure 3. The Role of Non-genetic Contribution to the Intergenerational Transmission of Health Inequality.

No matter what kind of epigenetic modification, its ultimate goal is to realize the regulation of specific gene expression and then affect the biological behavior of the individual. It finally appeared in a different state of health (32). Moreover, this epigenetic change at the molecular level will continue to exist in the affected individuals and will affect the biological behavior of the offspring along with fertilization and the behavior of the parents after the offspring is born.

\section{Genetic Polymorphism}

Genetic polymorphisms are the simultaneous occurrence of two or more discontinuous genotypes or alleles in a population (33). It determines the diversity of individuals (34). In general, a susceptible gene is strongly associated with an individual's susceptibility to a particular disease (35). Moreover, the internal and external environment will cause significant alterations in the expression of a susceptible gene related to the occurrence of a specific disease (36). Buck and colleagues found that the CHRNA5 single nucleotide polymorphism rs16969968, which leads to an aspartic acid to asparagine substitution at amino acid position $398(\mathrm{D} 398 \mathrm{~N})$ in the alpha-5 nicotinic acetylcholine receptor subunit, i.e., N397 variant, may protect against the intergenerational transmission of DNE-induced neurodevelopmental disorder-like behaviors in mice (37). Parent (G1) maternal acceptance was associated with higher offspring (G2) acceptance among those G2 participants with the oxytocinergic (OXTR) rs1042778 GG/GT genotype, but not among those with the TT genotype, indicating that oxytocinergic genes may influence sensitivity to the quality of parent-child relationship (38). In addition, women with a high OXTR expressing genotype rs237895 are more susceptible to childhood maltreatment-related impairments in maternal behavior that, in turn, predict attachment security in their children, supporting the role of the oxytocin system in the intergenerational transmission of risk associated with maternal childhood maltreatment (39). Although the evidence of genetic polymorphism in the intergenerational transmission of health inequality is not robust, it still can be seen from the available data regarding its contributing role in health inequality carried on between generations.

\section{Small Non-coding RNAs}

Since the discovery of micro RNAs (miRNAs) in 1993 (40), a number of different types of small RNAs with $<40$ nts have been discovered that play critical roles in biology. Small RNAs include miRNAs, endogenous silencing RNAs (endo-siRNAs), and the germ-line enriched P-element induced wimpy testis (piwi)-interacting RNAs (piRNAs). They take part in the processes of transcriptional regulation (transcriptional regulation by targeting DNA methylation and repressive chromatin formation), post-transcriptional regulation (degradation or deadenylation of target RNA), and translational repression (41).

The implication of sperm small RNAs in the intergenerational inheritance of paternal environmental conditions was demonstrated by studies using direct microinjections of small RNAs purified from the sperm of exposed males into control zygotes (42). This study provided direct evidence that paternal environmental information could be transmitted through sperm small RNAs. Other studies observed stress-related behavior inheritance from the paternal side by small RNAs mechanism (43, 44). Similarly, tRFs potentially act as epigenetic information carriers of paternal dietary information (45). Overall, these studies suggest that different environmental exposures direct distinct small RNA changes in sperm: diet majorly affects tRFs, whereas psychological stress influences miRNAs. Envi- 
ronmental changes function as an essential modulator to the sperm epigenome throughout life, but it would be more vulnerable at early developing stages like embryogenesis and primordial germ cell during which rapid cell division occurs.

\section{Health Characteristics with Inequality Property}

The intergenerational transmission of health inequality includes two major aspects: one is positive, and the other is negative. Positive health inequality means that when a person has health traits superior to others (such as Trait EI, Resilience, self-control, and generosity), the advantage is that they can more easily face and deal with difficult problems or psychological events they are facing, preventing them developing into severe consequences. This positive health inequality is showed up after comparison with those with a non-positive trait. It is a dominant feature and is worthy of encouraging and training. This kind of intergenerational transmission of positive inequality is expected to be obtained and has a particular inhibitory effect on negative counterparts. This review will only discuss above mentioned four favorable properties. Of course, when individuals lack these properties, their performance is naturally at a disadvantage. On the contrary, negative health inequality takes adverse life events as the carrier, harming individuals' physical and mental health. Moreover, in reality, most of them fall into this category.

\section{Positive Inequality of Health Characters Trait Emotional Intelligence}

Trait emotional intelligence (trait EI), the perceptions of people's emotional world, is a vast, hierarchical, multidimensional construct that could promote positive development in adolescents and predict affect-related outcomes (46). Individuals with high trait EI can efficiently deal with challenging conditions and generally have a good relationship with people around them. The development of emotional intelligence is a significant contributor to greater happiness and emotional well-being (47). It is an encouraging feature an individual should be trained to help get better psychological health that contributes to the overall health status, which could be passed on to successive generations.

\section{Resilience}

Resilience is the capacity to recover from difficult life events (48). It is beneficial for health by giving more flexibility in an individual's life. The higher this psychodynamic property an individual has, the easier it is for them to recover from the adversities, the healthier their lives would get. Eventually, they deserve more health bonuses (49). Compared with those with more and strong resilience, those with less and weak resilience would demonstrate low levels of flexibility, adaptability, and perseverance in their lives. Therefore, this is the difference of resilience among individuals when they cope with and work through challenging life experiences. That is inequality. When this kind of inequality of resilience is transmitted from generation to generation, it will inevitably get individuals to be prepared with a more flexible manner to face challenges if they got more resiliency.

\section{Self-Control}

Self-control is the ability an individual has to manage impulses, emotions, and behavior to execute function properly and the suite of skills that the individual can use to plan, monitor, and attain goals (50). Self-control is not self-deprivation, but it often redefines what is pleasurable to you to keep destructive behaviors in check. Through self-control, individuals can always avoid situations where they know they will confront temptation. For instance, if smoking is a big temptation, strong self-control will help stay away from smoking triggers (51). Of course, weak self-control will quickly get individuals trapped by destructive behaviors that negatively affect their overall health state. Self-control can be transmitted intergenerationally through offspring's attachment to parental models $(52,53)$. Even the level of self-control tends to wax and wane over a day. In contrast, it allows people to direct their attention despite challenging competing stimuli and underlies their achievements.

When people fall into the trap of temptations like drugs and food, their life and health will undoubtedly change as a consequence. These changes will cause significant changes in their cellular epigenetic traits that subsequently pass on to subsequent generations. This is obvious in families where specific family-favored stuff will pose a similar effect on both parents and children as found by Qiu and Hou that family socio-demographic factors are strongly associated with their food preference, eating behavior, and physical activities, which eventually affects the overall health status of the family especially children and adolescents (54). Of course, parental self-control in this situation is crucial to the whole family's health. Therefore, strong self-control capability with the favored positive direction would contribute to developing a healthier lifestyle that will substantially improve the health state and benefit the intergenerational transmission of self-control-related good health, or vice versa.

\section{Generosity}

Unlike pure altruism, generosity is a learned character trait that involves both attitude and action from which the moral good is expressed. Still, the vices rejected such as greed, selfishness, and fear. Generosity was not just a virtue of individuals but a corporate responsibility, institutionalized in myriad ways (55). The study from Wilhelm and colleagues showed that generosity could be transmitted down to children from their charitable parents (56). Cumulating evidence indicated that generosity could improve health by lowering blood pressure (57), reducing stress and depression levels (58), reducing inflammatory cytokine levels of interleukin-6 (59), and longer life expectancy (60). Not just the positive contribution of generosity produced to the overall health, but its role in helping givers and their family members' generous property more at the molecular level, and this health-beneficial characteristic could transmit down to upcoming new generations. However, the opposite situation is greedy and mean that work differently. To promote a healthier life, generosity is strongly suggested but not greediness.

\section{Negative Inequality of Health Characters}

We have to face many health-related inequalities throughout our lives, and most of them are negative. However, regardless of the level and degree of adverse health inequality, transmission be- 
tween generations naturally exists and cannot be avoided Therefore, we herein in this review will only focus on trauma, violence and abuse, and addiction as an example.

\section{Trauma}

Experiencing severe traumatic events, like wars, Holocaust, genocide, catastrophic events, car accidents, etc., would cause responsive changes physically and psychologically that dramatically impact patients' health through underlying molecular mechanisms at the cellular level. The evidence of intergenerational traumatic transmission first appeared in 1966 with the report of behavioral problems in the offspring of Holocaust survivors (61). Almost all the traumatic suffers experience psychological and psychiatric stress that lasts the whole life long for the patient and subsequently transmits down to their upcoming generations.

For traumatic injuries, the victims are often passively suffering. The harm caused by the trauma is the indirect contributor to the intergenerational transmission, but not the trauma itself (62). In most cases, the victims themselves are unwilling to repeat their traumatic experiences, let alone become another producer of similar trauma. Under normal and sensible circumstances, they will use the trauma as educational material to inform and remind latecomers to avoid such a bad experience (63). However, in sporadic cases, trauma victims will also evolve into perpetrators of similar trauma (64). Take China's Cultural Revolution, for example. Due to abnormal historical and environmental factors, many victims of the Cultural Revolution have become perpetrators after a period of time $(65,66)$. Although many possible factors can trigger its change, the biological traces of its experience on its body and psychology cannot be erased. This is precisely the initiating factor leading to the fundamental difference. Therefore, how to break the cycle of negative health inequality caused by trauma requires a strong sense of justice, responsibility, self-control, and a fair and just social and political environment.

Furthermore, resilience capability will significantly help if traumatic individuals possess this flexible psychological well-being. If all these are not the case, catastrophic trauma will undoubtedly harm the health of the individual and will lead to the intergenerational transmission of health inequality. As for how many generations of health inequality caused by this impact can be passed between generations or the suppression lasts, there is currently no available evidence to rely on.

\section{Violence and Abuse}

Whether it is violence or abuse, both will have a tremendous negative impact on the victim's body and mind and even lead to PTSD (67). Although it is controversial whether this external, violent, or abusive behavior is transmitted between generations (68), the transmission tendency of this behavior is evident. From a statistical point of view, it may be "none", but as far as the individual is concerned, many realistic examples and empirical studies provide a solid foundation for it, that is, "yes". Of course, we can't conclude as "no" just because of a meta-analysis. Because the potential physiological and psychological effects of violent or abusive behavior are significant, and its epigenetic changes at the cellular and molecular levels are more powerful
(69). Here we cannot deny the possible transmission of the harm caused by this behavior between generations based on a meta-analysis alone.

Violence or abuse is intense negative stress (70). Moreover, cumulating evidence showed that abused parents are at increased risk for perpetuating maladaptive parenting practices, which would be transmitted to generations to come through not just intimate $(71,72)$, but also the underlying uncontrollable epigenetic mechanisms (73).

No matter what age this kind of violence or abuse occurs, its direct or indirect impact cannot be fully explained simply by one type of research methodology. Most of the time, it is not the victim who repeats the violence or abuse they have experienced deliberately but does it involuntarily. The most important thing is that the trauma it suffered is like a time bomb; some tiny events will inadvertently trigger to repeat the violent or abusive behavior (74). But this time, the perpetrator and the victim have changed. Therefore, this transition from "being abused" to "abusing" is precisely an example of intergenerational transmission.

This kind of intense stress causes great harm to individual health, and it will inevitably be passed on between generations. Therefore, how to curtail the cycle of violence is critical. This will not only improve the physical and psychological health of the victims themselves but also be essential protection for the health of their offspring.

\section{Addiction}

Case \#3: A 52-year-old single Hispanic male, a construction worker, had right kidney clear cell carcinoma and right leg superficial femoral artery (SFA) occlusion. He underwent a right kidney nephrectomy and right SFA femoropopliteal bypass graft. The patient smokes over 35 years with 1.5 packs per day. He tried twice to quit but fell off the wagon. Currently, he smokes 0.5 packs per day post surgeries. The patient's family members, including parents and older brothers, are smokers or tobacco product users. His father died from lung cancer at age 56 years of age. Mother had two times of deep vein thrombosis and right below-knee amputation due to Burger's disease diagnosed at her 50 years old. One of his older brothers has had the chronic obstructive pulmonary disease for ten years since his 40 years of age. No family history of genetic diseases. This is a typical case of intergenerational transmission of healthy inequality caused by unhealthy living habits.

Studies have shown that regardless of timing, offspring exposure to maternal smoking is associated with increased risk of smoking during adolescence (75). And this type of transmission strongly correlated with parental smoking habits if they had an early onset, steep acceleration, high levels of smoking, and persistence over time, which pose the highest risk for transmitting the smoking behavior to their adolescent children (76). Besides smoking, other types of addictive behaviors, including drinking (77), drugs (78), sex (79), gambling (80), and foods (81), all possess dramatic effects on their transfer to successive generations.

No matter what kind of addiction an individual has, it will dramatically change their living habits and behavior that signif- 
icantly affect their health and socioeconomic status. Addiction itself causes substantial changes in the brain, not just at the molecular level but also at the brain's structure. For addicted individuals, activating the rewarding neuronal system is the most recognized underlying mechanism of addiction (82-85). However, it is merely the tip of the iceberg. The worst thing is its transmissible property between generations. As the case indicated above, addicted objects like tobacco products can get the addicting behavior passed on from parental generation to children, which unavoidably threatens sound health (86-88). We herein do not talk about the potential underlying mechanisms of addiction but the debilitating effect of addiction on health that transmits intergenerationally.

\section{Pandemic Stress}

Like the Coronavirus Disease 2019 (COVID-19), when the world is overwhelmed by a pandemic, everyone in it is a victim who cannot escape (89). When faced with the reality of vast numbers of deaths, when experiencing panic and fear while suffering from unemployment, and when various social interactions are restricted indefinitely, the individual's physical and mental health is on the verge of extreme danger $(90,91)$. For those with low psychological quality, low resilience, and insufficient social support, tragedies occur after suffering mental health, and extreme behaviors such as suicide occur (92-94).

At present, no one can predict the negative impact of the COVID-19 pandemic on the overall health of humans (95), nor is it clear how its impact will be transmitted between generations after it disappears in the future. But one sure thing is that we all hope that COVID-19 can end as soon as possible and return to everyday life $(96,97)$.

No matter how many unknown secrets there are in the occurrence of the COVID-19 pandemic (98), as an individual, the changes in his health after suffering from external environmental stress cannot be ignored. Although the impact of COVID-19 on the overall future health itself is not the focus of this review, the transmission of its potential health effects between generations may be more critical. The health inequality caused is directly related to the individual's physical and mental health. This effect will most likely exist in the future generations of offspring and adversely affect their health. Unfortunately, because the pandemic is still ongoing, so we still cannot get to know precisely the potential long-term health effects it will have.

\section{Conclusion and Perspective}

No matter what kind of environmental stress, and no matter what underlying mechanisms, its impact on an individual's health is not only on the suffers themselves, but more importantly, its impact on the health of offspring. This intergenerational transmission of poor health is the culprit of the intergenerational cycle of health inequality mediated by non-genetic factors. From the basic concept of health, i.e., the comprehensive performance of social, psychological, and biological (99), we know that social and psychological are essential components of biological health. They are precisely the external contributors to the occurrence of health inequality. Meanwhile, it is also crucial for transmitting this inequality between generations (100). Biological health inequality is the main result mediated by genetics, and it is health in a narrow sense. It is closely related to social and psychological health. In mind, an socially, psychologically, and biologically healthy individual has a relatively low proportion of health inequality, so the probability of transmission of health inequality between generations is considerably reduced (101). Therefore, we present the following prospective suggestion to effectively alleviate the health differences caused by inequality to reduce intergenerational transmission.

First, good social relationships and positive psychological responses are essential factors for maintaining health. Although the biological health of an individual may be problematic, effective social relationship adjustment and powerful psychological intervention will have a positive impact on the overall health. At the same time, it will also be an effective tool to block the intergenerational transmission of health inequality. Of course, the intervention of biological health problems with effective medical methods will also significantly improve the health of individuals and delay the intergenerational transmission of unfavorable health.

Second, although the economy has a direct and vital impact on health, the help of society, including the community, may play a positive role in the overall health of individuals under the premise of working hard to improve their economic conditions. Among them, Medicaid is a good example. It can be said with certainty that timely financial assistance is beneficial for the individual's physical and mental health. In this regard, we suggest that government decision-making departments should fully consider the overall economic situation; and give individuals appropriate compensation. Of course, the premise is that a person can develop laziness by offering it for free, which is counterproductive. Regardless of the various economic compensation measures, the administrator should consider the desired effect thoroughly.

Third, parents should try their best to consciously experience positive life and social events so that the epigenetic characteristics caused by the environment can be passed on to their offspring in a more positive way. Thus, reducing the probability of intergenerational transmission of healthy inequality, that is, to achieve optimal and healthy intergenerational transmission to achieve the gradual reduction of inequality as the generations pass down.

Fourth, health results from a combination of genetic and non-genetic factors. The change depends on the integration of both contributors. No matter which factors, the final result is the embodiment of a sub-representative. When humans cannot control genetic factors, non-genetic factors have become the key to acquired attention. It is also the hope of breaking the intergenerational reaction chain of health inequality. The possible intervention of non-genetic factors will be particularly effective for the intergenerational transmission of non-genetic health inequality. - 


\section{References}

1. United Nations. UNDESA World Social Report 2021. Last access: December 21, 2021; Available at: https://www.un.org/development/desa/dspd/world-so cial-report/2021-2.html

2. Peterson EWF. Is economic inequality really a problem? A review of the arguments. Soc Sci 2017; 6:147. DOI: https://doi.org/10.3390/socsci6040147

3. Scheffer M, van Bavel $B$, van de Leemput IA, van Nes EH. Inequality in nature and society. Proc Natl Acad Sci USA 2017; 114(50):13154-13157. doi: https://doi.org/10.1073/pnas.1706412114

4. Schoder D. Is a globalized world a less equal world? The relationship between globalization and inequality is not always straightforward. June 15, 2018. Last access: December 21, 2021; Available at: https://www.aeaweb.org/research/globalization-inco me-inequality-trade-policy

5. Lee SY, Seshadri A. On the Intergenerational Transmission of Economic Status. J Polit Econ 2019; 127(2):855-921. DOI: https://doi.org/10.1086/700765

6. Reiter D, Palz MT, Kreimer M. Intergenerational transmission of economic success in Austria with a focus on migration and gender. J Labour Market Res 2020; 54:6. DOI: https://doi.org/10.1186/s12651-020-00272-y

7. Myatra SN, Tripathy S, Einav S. Global health inequality and women - beyond maternal health. Anaesthesia 2021; 76 Suppl 4:6-9. DOI: https://doi.org/10.1111/anae.15431

8. Levy JI. Accounting for Health Risk Inequality in Regulatory Impact Analysis: Barriers and Opportunities. Risk Anal 2021; 41(4):610-618. DOI: https://doi.org/10.1111/risa.13714

9. Arcaya MC, Arcaya AL, Subramanian SV. Inequalities in health: definitions, concepts, and theories. Glob Health Action 2015; 8:27106. DOI: https://doi.org/10.3402/gha.v8.27106

10. Mengelkoch S, Hill SE. Early life disadvantage, phenotypic programming, and health disparities. Curr Opin Psychol 2020; 32:32-37. DOI: https://doi.org/10.1016/j.copsyc.2019.06.014

11. Rodríguez-Planas N, Sanz-de-Galdeano A. Intergenerational transmission of gender social norms and teenage smoking. Soc Sci Med 2019; 222:122-132. DOI: https://doi.org/10.1016/i.socscimed.2018.11.005

12. Almquist YB, Bishop L, Gustafsson NK, Berg L. Intergenerational transmission of alcohol misuse: mediation and interaction by school performance in a Swedish birth cohort. J Epidemiol Community Health 2020; 74(7):598-604. DOI:

https://doi.org/10.1136/jech-2019-213523

13. National Academies of Sciences, Engineering, and Medicine; Health and Medicine Division; Board on Population Health and Public Health Practice; Committee on Community-Based Solutions to Promote
Health Equity in the United States; Baciu A, Negussie Y, Geller A, et al., editors. Communities in Action: Pathways to Health Equity. Washington (DC): National Academies Press (US); 2017 Jan 11. 3, The Root Causes of Health Inequity. Available at: https://www.ncbi.nlm.nih.gov/books/NBK425845/

14. Braveman $P$, Gottlieb $L$. The social determinants of health: It's time to consider the causes of the causes. Public Health Rep 2014; 129(Suppl 2):19-31. DOI: https://doi.org/10.1177/00333549141291S206

15. World Health Organization. Health inequities and their causes. Last access: December 24, 2021. Available at:

https://www.who.int/news-room/facts-in-pictures/detai I/health-inequities-and-their-causes

16. Lynch J, Smith GD, Harper S, Hillemeier M, Ross N, Kaplan GA, Wolfson M. Is income inequality a determinant of population health? Part 1 . A systematic review. Milbank Q 2004; 82(1):5-99. DOI: https://doi.org/10.1111/i.0887-378x.2004.00302.x

17. Chetty R, Stepner M, Abraham S, Lin S, Scuderi B, Turner N, Bergeron A, Cutler D. The association between income and life expectancy in the United States, 2001-2014. JAMA 2016; 315(16):1750-1766. DOI: https://doi.org/10.1001/jama.2016.4226. Erratum in: JAMA 2017; 317(1):90.

18. Conger RD, Conger KJ, Martin MJ. Socioeconomic Status, Family Processes, and Individual Development. J Marriage Fam 2010; 72(3):685-704. DOI: https://doi.org/10.1111/j.1741-3737.2010.00725.x

19. Wu Y, Qi D. The Effects of family income and parents educational status on child health status: Examining the mediation effects of material deprivation and parents' health. J Fam Iss 2021; In press. DOI: https://doi.org/10.1177/0192513X211030733

20. Banovcinova A, Levicka J, Veres M. The Impact of Poverty on the Family System Functioning. Procedia Soc Behav Sci 2014; 132:148-153. DOI: https://doi.org/10.1016/j.sbspro.2014.04.291

21. Xavier MJ, Roman SD, Aitken RJ, Nixon B. Transgenerational inheritance: How impacts to the epigenetic and genetic information of parents affect offspring health. Hum Reprod Update 2019; 25(5):518-540. DOI: https://doi.org/10.1093/humupd/dmz017

22. Goswami R, Subramanian G, Silayeva L, Newkirk I, Doctor D, Chawla K, Chattopadhyay S, Chandra D, Chilukuri N, Betapudi V. Gene Therapy leaves a vicious cycle. Front Oncol 2019; 9:297. DOI: https://doi.org/10.3389/fonc.2019.00297

23. Jackson M, Marks L, May GHW, Wilson JB. The genetic basis of disease. Essays Biochem 2018; 62(5):643-723. DOI: https://doi.org/10.1042/EBC20170053. Erratum in: Essays Biochem 2020; 64(4):681.

24. Cheng TL, Johnson SB, Goodman E. Breaking the 
intergenerational cycle of disadvantage: The three generation approach. Pediatrics 2016;

137(6):e20152467. DOI:

https://doi.org/10.1542/peds.2015-2467

25. Zhang L, Lu Q, Chang C. Epigenetics in health and disease. Adv Exp Med Biol 2020; 1253:3-55. DOI: https://doi.org/10.1007/978-981-15-3449-2 1

26. Kaliman P. Epigenetics and meditation. Curr Opin Psychol 2019; 28:76-80. DOI: https://doi.org/10.1016/j.copsyc.2018.11.010

27. Legoff L, D'Cruz SC, Tevosian S, Primig M, Smagulova F. Transgenerational inheritance of environmentally induced epigenetic alterations during mammalian development. Cells 2019; 8(12):1559. DOI: https://doi.org/10.3390/cells8121559

28. Tuscher JJ, Day JJ. Multigenerational epigenetic inheritance: One step forward, two generations back. Neurobiol Dis 2019; 132:104591. DOI: https://doi.org/10.1016/j.nbd.2019.104591

29. Tiffon C. The Impact of Nutrition and Environmental Epigenetics on Human Health and Disease. Int J Mol Sci 2018; 19(11):3425. DOI: https://doi.org/10.3390/ijms19113425

30. Hu Y, Bobak M. Upward intergenerational transmission of health inequality. J Epidemiol Community Health 2018; 72(11):971-972. DOI: https://doi.org/10.1136/jech-2018-211282

31. Branje S, Geeraerts S, de Zeeuw EL, Oerlemans AM, Koopman-Verhoeff ME, Schulz S, Nelemans S, Meeus W, Hartman CA, Hillegers MHJ, Oldehinkel AJ, Boomsma DI. Intergenerational transmission: Theoretical and methodological issues and an introduction to four Dutch cohorts. Dev Cogn Neurosci 2020; 45:100835. DOI: https://doi.org/10.1016/i.dcn.2020.100835

32. Weinhold B. Epigenetics: The science of change. Environ Health Perspect 2006; 114(3):A160-A167. DOI: https://doi.org/10.1289/ehp.114-a160

33. Ismail S, Essawi M. Genetic polymorphism studies in humans. Mid East J Med Genet 2012; 1(2):57-63. DOI: https://doi.org/10.1097/01.MXE.0000415225.85003.4 7

34. Ma ZS, Li L, Zhang YP. Defining individual-level genetic diversity and similarity profiles. Sci Rep 2020; 10(1):5805. DOI: https://doi.org/10.1038/s41598-020-62362-8

35. Burgner D, Jamieson SE, Blackwell JM. Genetic susceptibility to infectious diseases: Big is beautiful, but will bigger be even better? Lancet Infect Dis 2006; 6(10):653-663. DOI:

https://doi.org/10.1016/S1473-3099(06)70601-6

36. Ho SM, Johnson A, Tarapore P, Janakiram V, Zhang $X$, Leung YK. Environmental epigenetics and its implication on disease risk and health outcomes. ILAR J 2012; 53(3-4):289-305. DOI:

https://doi.org/10.1093/ilar.53.3-4.289. Erratum in: ILAR J 2017; 58(3):413.

37. Buck JM, O'Neill HC, Stitzel JA. The intergenerational transmission of developmental nicotine exposure-induced neurodevelopmental disorder-like phenotypes is modulated by the Chrna5 D397N polymorphism in adolescent mice. Behav Genet 2021; 51(6):665-684. DOI:

https://doi.org/10.1007/s10519-021-10071-x

38. Savelieva K, Hintsanen M, Dobewall H, Jokela M, Pulkki-Råback L, Elovainio M, Seppälä I, Lehtimäki T, Raitakari O, Keltikangas-Järvinen L. The role of oxytocinergic genes in the intergenerational transmission of parent-child relationship qualities. Horm Behav 2019; 114:104540. DOI: https://doi.org/10.1016/i.yhbeh.2019.06.004

39. Toepfer P, O'Donnell KJ, Entringer S, Heim CM, Lin DTS, Maclsaac JL, Kobor MS, Meaney MJ, Provençal N, Binder EB, Wadhwa PD, Buss C. A role of oxytocin receptor gene brain tissue expression quantitative trait locus rs237895 in the intergenerational transmission of the effects of maternal childhood maltreatment. J Am Acad Child Adolesc Psychiatry 2019; 58(12):1207-1216. DOI: https://doi.org/10.1016/j.jaac.2019.03.006

40. Lee RC, Feinbaum RL, Ambros V. The C. elegans heterochronic gene lin-4 encodes small RNAs with antisense complementarity to lin-14. Cell 1993; 75(5):843-854. DOI: https://doi.org/10.1016/0092-8674(93)90529-y

41. Catalanotto C, Cogoni C, Zardo G. MicroRNA in control of gene expression: An overview of nuclear functions. Int J Mol Sci 2016; 17(10):1712. DOI: https://doi.org/10.3390/ijms17101712

42. Gapp K, Jawaid A, Sarkies P, Bohacek J, Pelczar P, Prados J, Farinelli L, Miska E, Mansuy IM. Implication of sperm RNAs in transgenerational inheritance of the effects of early trauma in mice. Nat Neurosci 2014 17(5):667-669. DOI: https://doi.org/10.1038/nn.3695

43. Rodgers AB, Morgan CP, Bronson SL, Revello S, Bale TL. Paternal stress exposure alters sperm microRNA content and reprograms offspring HPA stress axis regulation. J Neurosci 2013; 33(21):9003-9012. DOI: https://doi.org/10.1523/JNEUROSCI.0914-13.2013

44. Rodgers AB, Morgan CP, Leu NA, Bale TL. Transgenerational epigenetic programming via sperm microRNA recapitulates effects of paternal stress. Proc Natl Acad Sci USA 2015; 112(44):13699-13704. DOI: https://doi.org/10.1073/pnas.1508347112

45. Chen Q, Yan M, Cao Z, Li X, Zhang Y, Shi J, Feng GH, Peng H, Zhang X, Zhang Y, Qian J, Duan E, Zhai $Q$, Zhou Q. Sperm tsRNAs contribute to intergenerational inheritance of an acquired metabolic disorder. Science 2016; 351(6271):397-400. DOI: https://doi.org/10.1126/science.aad7977

46. Costa S, Barberis N, Gugliandolo MC, Larcan R, Cuzzocrea F. The intergenerational transmission of trait emotional intelligence: The mediating role of parental autonomy support and psychological control. J Adolesc 2018; 68:105-116. DOI: https://doi.org/10.1016/i.adolescence.2018.07.008

47. Guerra-Bustamante J, León-Del-Barco B, Yuste-Tosina R, López-Ramos VM, Mendo-Lázaro S. Emotional intelligence and psychological well-being in adolescents. Int J Environ Res Public Health 2019; 16(10):1720. DOI: 
https://doi.org/10.3390/ijerph16101720

48. Wu G, Feder A, Cohen H, Kim JJ, Calderon S, Charney DS, Mathé AA. Understanding resilience. Front Behav Neurosci 2013; 7:10. DOI: https://doi.org/10.3389/fnbeh.2013.00010

49. Sisto A, Vicinanza F, Campanozzi LL, Ricci G, Tartaglini D, Tambone V. Towards a transversal definition of psychological resilience: A literature review. Medicina (Kaunas) 2019; 55(11):745. DOI: https://doi.org/10.3390/medicina55110745

50. Duckworth AL, Gendler TS, Gross JJ. Situational strategies for self-control. Perspect Psychol Sci 2016; 11(1):35-55. DOI: https://doi.org/10.1177/1745691615623247

51. Baumeister RF. Addiction, cigarette smoking, and voluntary control of action: Do cigarette smokers lose their free will? Addict Behav Rep 2017; 5:67-84. DOI: https://doi.org/10.1016/j.abrep.2017.01.003

52. Bridgett DJ, Burt NM, Edwards ES, Deater-Deckard K. Intergenerational transmission of self-regulation: $A$ multidisciplinary review and integrative conceptual framework. Psychol Bull 2015; 141(3):602-654. DOI: https://doi.org/10.1037/a0038662

53. Shah PE, Fonagy P, Strathearn L. Is attachment transmitted across generations? The plot thickens. Clin Child Psychol Psychiatry 2010; 15(3):329-345. DOI: https://doi.org/10.1177/1359104510365449

54. Qiu C, Hou M. Association between food preferences, eating behaviors and socio-demographic factors, physical activity among children and adolescents: A Cross-sectional study. Nutrients 2020; 12(3):640. DOI: https://doi.org/10.3390/nu12030640

55. [No author list] What is Generosity? Last accessed: December 7, 2021. Available at:

https://generosityresearch.nd.edu/more-about-the-init iative/what-is-generosity/

56. Wilhelm MO, Brown E, Rooney PM, Steinberg R. The Intergenerational transmission of generosity. J Public Econ 2008; 92(10-11):2146-2156. DOI: https://doi.org/10.1016/j.jpubeco.2008.04.004

57. Sneed RS, Cohen S. A prospective study of volunteerism and hypertension risk in older adults. Psychol Aging 2013; 28(2):578-586. DOI: https://doi.org/10.1037/a0032718

58. Jenkinson CE, Dickens AP, Jones K, Thompson-Coon J, Taylor RS, Rogers M, Bambra CL, Lang I, Richards $\mathrm{SH}$. Is volunteering a public health intervention? A systematic review and meta-analysis of the health and survival of volunteers. BMC Public Health 2013; 13:773. DOI: https://doi.org/10.1186/1471-2458-13-773

59. Jiang T, Yakin S, Crocker J, Way BM. Perceived social support-giving moderates the association between social relationships and interleukin- 6 levels in blood. Brain Behav Immun 2021; 100:25-28. DOI: https://doi.org/10.1016/j.bbi.2021.11.002

60. Vogt T, Kluge F, Lee R. Intergenerational resource sharing and mortality in a global perspective. Proc Natl Acad Sci USA 2020; 117(37):22793-22799. DOI: https://doi.org/10.1073/pnas.1920978117. Erratum in: Proc Natl Acad Sci USA 2020; 117(42):26533. DOI: https://doi.org/10.1073/pnas.2019137117

61. Rakoff $\mathrm{V}$. A long term effect of the concentration camp experience. Viewpoints 1966; 1: 17-22.

62. Yehuda R, Lehrner A. Intergenerational transmission of trauma effects: Putative role of epigenetic mechanisms. World Psychiatry 2018; 17(3):243-257. DOI: https://doi.org/10.1002/wps.20568

63. Carello J, Butler LD. Potentially perilous pedagogies: Teaching trauma is not the same as trauma-informed teaching. J Trauma Dissociation 2014; 15(2):153-68. DOI: https://doi.org/10.1080/15299732.2014.867571

64. Levy MS. A helpful way to conceptualize and understand reenactments. J Psychother Pract Res 1998; 7(3):227-235.

65. Thurston AF. Victims of China's Cultural Revolution: The invisible wounds: Part I. Pacific Affairs 1984; 57(4): 599-620. DOI: https://doi.org/10.2307/2758711

66. Wang Y. The political legacy of violence during China's Cultural Revolution. Brit J Polit Sci 2019; 2019:1-25. DOI: https://doi.org/10.1017/S0007123419000255

67. Raman U, Bonanno PA, Sachdev D, Govindan A, Dhole A, Salako O, Patel J, Noureddine LR, Tu J, Guevarra-Fernández J, Leto A, Nemeh C, Patel A, Nicheporuck A, Tran A, Kennedy CA. Community violence, PTSD, hopelessness, substance use, and perpetuation of violence in an urban environment. Community Ment Health J 2021; 57(4):622-630. DOI: https://doi.org/10.1007/s10597-020-00691-8

68. Haselschwerdt ML, Savasuk-Luxton R, Hlavaty K. A methodological review and critique of the "intergenerational transmission of violence" literature. Trauma Violence Abuse 2019; 20(2):168-182. DOI: https://doi.org/10.1177/1524838017692385

69. Krause BJ, Artigas R, Sciolla AF, Hamilton J. Epigenetic mechanisms activated by childhood adversity. Epigenomics 2020; 12(14):1239-1255. DOI: https://doi.org/10.2217/epi-2020-0042

70. Nyarko F, Peltonen K, Kangaslampi S, Punamäki-Gitai RL. How stressful life events and violence are related to mental health: The protective role of social relations in African context. Heliyon 2020; 6(8):e04629. DOI: https://doi.org/10.1016/j.heliyon.2020.e04629

71. Minh A, Matheson FI, Daoud N, Hamilton-Wright S, Pedersen C, Borenstein H, O'Campo P. Linking childhood and adult criminality: using a life course framework to examine childhood abuse and neglect substance use and adult partner violence. Int J Environ Res Public Health 2013; 10(11):5470-5489. DOI: https://doi.org/10.3390/ijerph10115470

72. Forke CM, Catallozzi M, Localio AR, Grisso JA, Wiebe DJ, Fein JA. Intergenerational effects of witnessing domestic violence: Health of the witnesses and their children. Prev Med Rep 2019; 15:100942. DOI: https://doi.org/10.1016/j.pmedr.2019.100942

73. Ramo-Fernández L, Boeck $C$, Koenig AM, Schury $K$, Binder EB, Gündel H, Fegert JM, Karabatsiakis A, Kolassa IT. The effects of childhood maltreatment on epigenetic regulation of stress-response associated genes: An intergenerational approach. Sci Rep 2019; 
9(1):983. DOI:

https://doi.org/10.1038/s41598-018-36689-2

74. Center for Substance Abuse Treatment (US). Trauma-Informed Care in Behavioral Health Services. Rockville (MD): Substance Abuse and Mental Health Services Administration (US); 2014. (Treatment Improvement Protocol (TIP) Series, No. 57.) Chapter 2 , Trauma Awareness. Available from: https://www.ncbi.nlm.nih.gov/books/NBK207203/

75. Chadi N, Ahun MN, Laporte C, Boivin M, Tremblay $\mathrm{RE}$, Côté SM, Orri M. Pre- and postnatal maternal smoking and offspring smoking trajectories: Evidence from a 20-year birth cohort. Prev Med 2021; 147:106499. DOI: https://doi.org/10.1016/i.ypmed.2021.106499

76. Chassin L, Presson C, Seo DC, Sherman SJ, Macy J, Wirth RJ, Curran P. Multiple trajectories of cigarette smoking and the intergenerational transmission of smoking: A multigenerational, longitudinal study of a Midwestern community sample. Health Psychol 2008; 27(6):819-828. DOI: https://doi.org/10.1037/0278-6133.27.6.819

77. Mares SH, Lichtwarck-Aschoff A, Engels RC. Intergenerational transmission of drinking motives and how they relate to young adults' alcohol use. Alcohol Alcohol 2013; 48(4):445-451. DOI: https://doi.org/10.1093/alcalc/agt025

78. Haggerty KP, Carlini BH. Understanding the intergenerational transmission of substance use and problem behavior: Implications for future research and preventive interventions. Psychol Addict Behav 2020; 34(8):894-897. DOI:

https://doi.org/10.1037/adb0000624

79. Jeon S, Neppl TK. The intergenerational transmission of externalizing behavior: The importance of a positive romantic partner. J Abnorm Child Psychol 2019; 47(11):1747-1758. DOI: https://doi.org/10.1007/s10802-019-00563-0

80. Dowling NA, Shandley K, Oldenhof E, Youssef GJ, Thomas SA, Frydenberg E, Jackson AC. The intergenerational transmission of problem gambling: The mediating role of parental psychopathology. Addict Behav 2016; 59:12-17. DOI: https://doi.org/10.1016/i.addbeh.2016.03.002

81. Baker CW, Whisman MA, Brownell KD. Studying intergenerational transmission of eating attitudes and behaviors: Methodological and conceptual questions. Health Psychol 2000; 19(4):376-381. DOI: https://doi.org/10.1037//0278-6133.19.4.376

82. Gardner EL. Addiction and brain reward and antireward pathways. Adv Psychosom Med 2011; 30:22-60. DOI: https://doi.org/10.1159/000324065

83. Koo G, Volkow N. Neurocircuitry of addiction. Neuropsychopharmacol 2010; 35:217-238. DOI: https://doi.org/10.1038/npp.2009.110

84. Volkow ND, Michaelides M, Baler R. The neuroscience of drug reward and addiction. Physiol Rev 2019; 99(4):2115-2140. DOI: https://doi.org/10.1152/physrev.00014.2018

85. Koob GF, Volkow ND. Neurobiology of addiction: A neurocircuitry analysis. Lancet Psychiatry 2016; 3(8):760-773. DOI:

\section{https://doi.org/10.1016/S2215-0366(16)00104-8}

86. Kerr DCR, Capaldi DM. Introduction to the special section on the intergenerational transmission of risk for substance use. Psychol Addict Behav 2020; 34(8):811-817. DOI: https://doi.org/10.1037/adb0000652

87. Gomez KL, Charles M. Mythological bridge between intergenerational transmission of unmourned loss and addiction. Psychoanal Rev 2020; 107(2):153-174 DOI: https://doi.org/10.1521/prev.2020.107.2.153

88. Haggerty KP, Carlini $\mathrm{BH}$. Understanding the intergenerational transmission of substance use and problem behavior: Implications for future research and preventive interventions. Psychol Addict Behav 2020; 34(8):894-897. DOI: https://doi.org/10.1037/adb0000624

89. The Center for Systems Science and Engineering (CSSE) at Johns Hopkins University (JHU).

COVID-19 dashboard. Last access: December 24, 2021. Available at: https://coronavirus.jhu.edu/map.html

90. Marroquín B, Vine V, Morgan R. Mental health during the COVID-19 pandemic: Effects of stay-at-home policies, social distancing behavior, and social resources. Psychiatry Res 2020; 293:113419. DOI: https://doi.org/10.1016/j.psychres.2020.113419

91. Sojli E, Tham WW, Bryant R, McAleer M. COVID-19 restrictions and age-specific mental health-U.S. probability-based panel evidence. Transl Psychiatry 2021; 11(1):418. DOI: https://doi.org/10.1038/s41398-021-01537-x

92. Tandon R. COVID-19 and suicide: Just the facts. Key learnings and guidance for action. Asian J Psychiatr 2021; 60:102695. DOI: https://doi.org/10.1016/j.ajp.2021.102695

93. Pirkis J, John A, Shin S, DelPozo-Banos M, Arya V, Analuisa-Aguilar P, Appleby L, Arensman E, Bantjes J, Baran A, Bertolote JM, Borges G, Brečić P, Caine E, Castelpietra G, Chang SS, Colchester D, Crompton D, Curkovic M, Deisenhammer EA, Du C, Dwyer J, Erlangsen A, Faust JS, Fortune S, Garrett A, George D, Gerstner R, Gilissen R, Gould M, Hawton K, Kanter J, Kapur N, Khan M, Kirtley OJ, Knipe D, Kolves K, Leske S, Marahatta K, Mittendorfer-Rutz E, Neznanov N, Niederkrotenthaler T, Nielsen E, Nordentoft M, Oberlerchner H, O'Connor RC, Pearson M, Phillips MR, Platt S, Plener PL, Psota G, Qin P, Radeloff D, Rados C, Reif A, Reif-Leonhard C, Rozanov V, Schlang C, Schneider B, Semenova N, Sinyor M, Townsend E, Ueda M, Vijayakumar L, Webb RT, Weerasinghe M, Zalsman G, Gunnell D, Spittal MJ. Suicide trends in the early months of the COVID-19 pandemic: An interrupted time-series analysis of preliminary data from 21 countries. Lancet Psychiatry 2021; 8(7):579-588. DOI: https://doi.org/10.1016/S2215-0366(21)00091-2. Erratum in: Lancet Psychiatry 2021; 8(11):e21.

94. Abi Zeid Daou M, Rached G, Geller J. COVID-19 and suicide: A deadly association. J Nerv Ment Dis 2021; 209(5):311-319. DOI: https://doi.org/10.1097/NMD.0000000000001338

95. Joint statement by ILO, FAO, IFAD and WHO. Impact 
of COVID-19 on people's livelihoods, their health and our food systems. Last access: December 24, 2021. Available at:

https://www.who.int/news/item/13-10-2020-impact-ofcovid-19-on-people's-livelihoods-their-health-and-our -food-systems

96. Shannon J. When will things go back to normal? Experts say that's the wrong question amid COVID-19. Published October 10, 2020. Last access: December 24, 2021. Available at:

https://www.usatoday.com/story/news/health/2020/10 110/coronavirus-when-return-to-normal-life/58828980 $\underline{021}$

97. Charumilind S, Craven M, Lamb J, Sabow A, Singhal $\mathrm{S}$, Wilson M. When will the COVID-19 pandemic end? Last access: December 24, 2021. Available at: https://www.mckinsey.com/industries/healthcare-syst ems-and-services/our-insights/when-will-the-covid-19 -pandemic-end

98. The BASE Medicine Task Force. Facts and recommendations of SARS-CoV-2 and COVID-19: An up- date. Sci Insig 2020; 35(1):194-215. DOI: https://doi.org/10.15354/si.20.re076

99. Hoffman SJ, Tan C. Biological, psychological and social processes that explain celebrities' influence on patients' health-related behaviors. Arch Public Health 2015; 73(1):3. DOI:

https://doi.org/10.1186/2049-3258-73-3

100.Pfeffer FT, Killewald A. Generations of advantage. multigenerational correlations in family wealth. Soc Forces 2018; 96(4):1411-1442. DOI: https://doi.org/10.1093/sf/sox086

101. National Academies of Sciences, Engineering, and Medicine; Health and Medicine Division; Board on Population Health and Public Health Practice; Committee on Community-Based Solutions to Promote Health Equity in the United States; Baciu A, Negussie Y, Geller A, et al., editors. Communities in Action: Pathways to Health Equity. Washington (DC): National Academies Press (US); 2017 Jan 11. 3, The Root Causes of Health Inequity. Available at: https://www.ncbi.nlm.nih.gov/books/NBK425845/

Received: July 16, 2021 ｜ Revised: November 21, $2021 \quad$ Accepted: November 27, 2021 